\title{
Migraçóes, pendularidades e mercado de trabalho no segmento upstream da indústria do petróleo na Bacia de Campos
}

Joseane Souza. Universidade Estadual do Norte Fluminense Darcy Ribeiro (UENF), Campos dos Goytacazes, Brasil.

Denise Terra. Universidade Estadual do Norte Fluminense Darcy Ribeiro (UEnf), Campos dos Goytacazes, Brasil.

RESUMO | Este artigo presenta uma análise da reestruturação produtiva ocorrida a mediados da década de 1970 na Bacia de Campos e seus reflexos no mercado de trabalho. Trata-se de um processo que se materializou em uma mudança desde atividades predominantemente orientadas até a agroindústria sucroalcooleira, às atividades dirigidas a exploração e produção de azeite e gás offshore. Analisaram-se, por meio de revisão bibliográfica, a reestruturação produtiva na região Norte Fluminense e as relaçôes teóricas entre pendularidade, migração e mercado de trabalho, e com apoio de dados censais, determinou-se a importância dessas variáveis no contexto da Bacia de Campos. Constatou-se que a mão de obra existente, além de não haver sido absorbida pela nova indústria, não se constituiu num exército industrial de reserva para a mesma e para as atividades conexas.

PALAVRAS CHAVE $\mid$ mercado de trabalho, reestruturação produtiva, migração.

ABSTRACT | This article presents an analysis of the productive restructuring that took place in the Campos Basin from the mid-1970s onwards, and its effects on the labor market, which shifted from a predominantly sugar-alcohol agroindustry to activities that focused on the exploration and production of oil and offshore gas. The productive restructuring in the Northern Fluminense region and the theoretical relations between pendularity, migration and the labor market were analyzed through a bibliographical review. Additionally, the importance of these variables in the context of the Campos Basin was identified through census data. Results show that the existing labor force, besides not having been absorbed by the new industry, did not constitute an industrial army reserve for the same and related activities.

KEYWORDS | labor market, productive restructuring, migration. 


\section{Introduçáo}

Este artigo objetiva analisar os reflexos da reestruturação produtiva ocorrida, a partir da segunda metade da década 1970, em municípios fluminenses produtores de petróleo, da Bacia de Campos (Rio de Janeiro/Brasil), assim denominada seguindo o Código (internacional) de Nomenclatura Estratigráfica, que adota para a Bacia o nome de uma cidade próxima ou acidente geográfico. Essa Bacia ocupada uma área de aproximadamente $100.000 \mathrm{~km}^{2}$ e se estende do estado do Espírito Santo até o litoral norte do estado do Rio de Janeiro. Neste artigo trataremos apenas dos municípios pertencentes ao estado do Rio de Janeiro, com exclusão de Niterói, por ser um município da região metropolitana com uma população significativamente superior à dos demais, e com uma economia mais diversificada. Os municípios selecionados, doravante denominados municípios da Bacia de Campos, localizam-se nas 'Baixadas Litorâneas' e no 'Norte Fluminense'.

A reestruturação produtiva implicou em uma série de impactos regionais. Um deles deu-se sobre o mercado de trabalho, tendo em vista que o novo setor produtivo se caracteriza por ser intensivo em capital, demandando, portanto, uma mão de obra bastante qualificada e significativamente diferente daquela demanda pelo setor sucroalcooleiro e salineiro. Nesse sentido, o artigo está organizado em seis seçôes, incluindo esta seção introdutória.

$\mathrm{Na}$ segunda serão apresentadas as principais características da reestruturação produtiva pela qual passaram esses municípios, assim como as principais características do novo mercado de trabalho. Na terceira seção, serão feitas considerações teóricas sobre a relação entre a mobilidade espacial da população (migração e movimentos pendulares) e distribuição espacial dos postos de trabalho; assim como sobre a mobilidade espacial como estratégia de ascensão social e de sobrevivência dos indivíduos no mercado, à luz de visóes críticas sobre a transferência intersetorial de mão de obra. Na quarta, serão apresentados resultados sobre os movimentos migratórios e pendulares no contexto do segmento upstream da indústria do petróleo na bacia de Campos. Na quinta, as consideraçôes finais e, na sexta, as referências bibliográficas.

\section{Reestruturaçáo produtiva nos municípios fluminenses produtores da Bacia de Campos}

Os municípios da Bacia de Campos localizados na Baixada Litorânea -Arraial do Cabo, Armaçáo dos Búzios, Cabo Frio, Casimiro de Abreu e Rio das Ostras- e no Norte Fluminense -Carapebus, Campos dos Goytacazes, Macaé, Quissamã e São João da Barra- podem ser visualizados na Figura 1. Observe que se trata de municípios litorâneos, tendo em vista que a produção de petróleo e gás, nesta região, dá-se em alto mar (off shore). Até recentemente, mais de $80 \%$ da produção petrolífera brasileira era extraída desta Bacia, gerando compensaçóes financeiras -royalties e participaçôes especiais- de grande volume para esses municípios. 


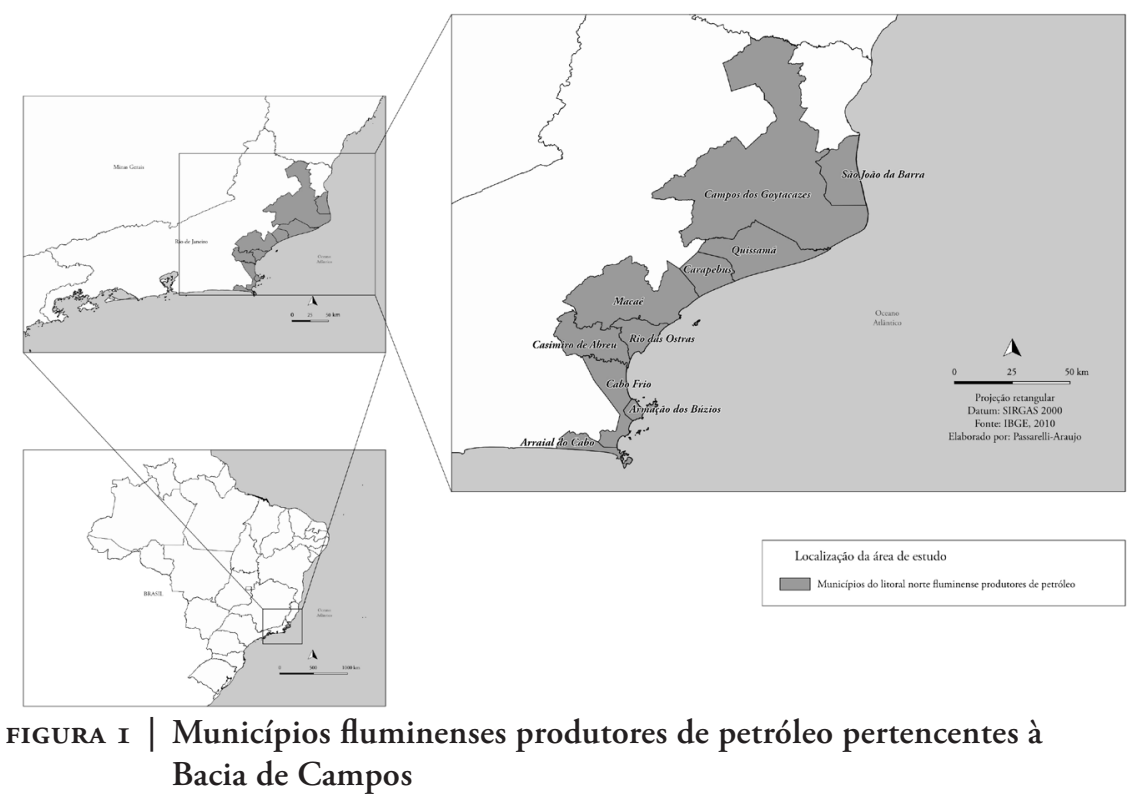

FONTE: MALHAS MUNICIPAIS, IBGE, 2010

Antes de se tornarem produtores de petróleo, os municípios da Baixada Litorânea se destacavam, no cenário econômico nacional, pelo desenvolvimento da atividade salineira, com a presença de empresas de grande porte como Companhia Salinas Perynas, Refinaria Nacional do Sal (RNs) e Companhia Nacional de Álcalis (CNA). Já os municípios do Norte Fluminense destacavam-se pela forte presença da indústria sucroalcooleira, sendo esta, com maior peso no PIB estadual comparativamente àquela.

Nos anos 1970 as indústrias salineira e sucroalcooleira entram em decadência, por motivos diversos, os quais náo discutiremos aqui. Este momento coincide com a descoberta de petróleo na Bacia de Campos, em 1973; a instalação da sede operacional da Petrobras em Macaé, em 1974; e o início das atividades de exploração, em 1977 , e marca o início de um novo ciclo econômico regional.

O enfraquecimento da agroindústria salineira e sucroalcooleira provocou a perda de dinamismo de importantes ramos da cadeia produtiva nestas regióes, reverberando nas demais atividades de comércio e serviços. A decadência desses setores gerou um contingente de mão de obra desempregada, pouco qualificada, e incapaz de ser absorvida pelo setor petrolífero. A propósito, desde o desenvolvimento deste setor,

(...) a dinâmica urbana e econômica dos municípios fluminenses (incluindo o poder público) estaria não somente associada, mas também dotada de maior dependência do setor petrolífero. Essa "dependência" variaria, em grau, em função do posicionamento do município dentro da divisão regional do trabalho da indústria petrolífera fluminense, sendo, assim, mais alta naqueles limítrofes à regiáo produtora da Bacia de Campos. (Silva \& Matos, 2016, p. 706) 
A indústria do petróleo é bem diferenciada das demais deste grupo, pois exige atividades de grande complexidade tecnológica e diversificadas tecnologias empregadas nas fases de perfuração e sondagem. Trata-se de uma indústria de produção contínua que apresenta dois grandes segmentos denominados de upstream ou montante e downstream ou jusante. O primeiro inclui as fases de exploraçáo, desenvolvimento e produção enquanto no segundo incluem-se as atividades de transporte, refino e distribuição. O maior volume de investimentos da indústria concentra-se no segmento upstream, quando são perfurados os poços produtores e instaladas as plataformas e equipamentos (Piquet \& Terra, 2011).

A atividade petrolífera na Bacia de Campos se expande significativamente a partir da Lei 9.478/97, conhecida como Lei do Petróleo e do Decreto 2.705/98, conhecido como Decreto das Participaçóes Especiais. A Lei do Petróleo elevou a alíquota dos royalties, antes fixada em $5 \%$ do valor da produção, para uma alíquota que varia de $5 \%$ a $10 \%$, beneficiando de forma extraordinária as finanças públicas dos seletos municípios confrontantes com os poços petrolíferos, denominados pela Lei de "municípios produtores" de petróleo e gás. Esta Lei decreta o fim do monopólio na exploração e produção de petróleo e gás no país permitindo a entrada de empresas estrangeiras, elevando significativamente a produção de petróleo e gás. A Bacia de Campos chegou a produzir mais de $80 \%$ do petróleo brasileiro e os municípios do Norte Fluminense, em especial Campos dos Goytacazes e Macaé tornaram-se os maiores beneficiários destas compensaçóes financeiras.

Para se entender o contexto em que ocorreu a elaboração da Lei do Petróleo é importante lembrar que a década de 1990 no Brasil foi marcada pelas reformas do Estado e abertura comercial influenciadas pela base teórica neoliberal. O Brasil passa por um processo de reestruturaçáo produtiva, decorrente da abertura comercial ampla propiciada pela redução das barreiras tarifárias à entrada de produtos no mercado nacional, gerando uma desarticulação de cadeias produtivas já consolidadas, desnacionalizaçáo de empresas e altas taxas de desemprego.

No setor petrolífero ocorreram importantes alteraçóes na política de compras da Petrobras em meados dos anos 1990, em especial na área do upstream, atribuídas aos acordos assinados com o Fundo Monetário Internacional (FMI), que considerava os investimentos das empresas estatais como aumento da dívida pública. Segundo Rappel (2003),

(...) das quinze plataformas flutuantes de produção adquiridas pela empresa naquele período, somente três foram construídas no Brasil, com investimentos da ordem de us $\$ 600$ milhóes; enquanto doze foram encomendadas a estaleiros no exterior (...) representando investimentos totais de us $\$ 2,3$ bilhôes, com participação nacional pouco expressiva, variando de zero a $20 \%$. (p. 99)

Este autor argumenta ainda que essas alterações resultaram na formação de um movimento empresarial de antigos fornecedores da Petrobras no sentido de buscar formas de atuação que contornassem essa situação que causou sérios prejuízos ao parque industrial brasileiro. A Agência Nacional do Petróleo (ANP), órgão regulador do setor após a flexibilização do monopólio estatal, orientada neste sentido, passou a criar exigências de conteúdo local, protegendo a cadeia produtiva já instalada, 
ampliando a participação nacional no fornecimento de bens e serviços para o setor petróleo e gás, recuperando e ampliando os empregos e a renda no País.

Como dito anteriormente, a indústria petrolífera é complexa e de risco, envolvendo nas suas diversas etapas empresas de diferentes portes e níveis de especialização. O papel mais importante é exercido pelas petroleiras (oil companies), que são intensivas em capital e que contratam serviços de sísmica, perfuração e produção de outras empresas especializadas, que requerem máo de obra qualificada em suas operaçóes.

Mas é importante destacar que existem também oportunidades para pequenas e médias empresas se tornarem fornecedoras das petroleiras tendo em vista a variedade de produtos demandados, envolvendo serviços de menor conteúdo tecnológico e desta forma criando oportunidades de trabalho para uma máo de obra menos qualificada.

A reestruturaçáo produtiva da indústria do petróleo reflete as tendências em curso no cenário internacional de reestruturação do capitalismo e suas manifestaçôes no mercado de trabalho. Nesta direção a adoção da terceirização foi decorrente da exigência de uma variedade de tarefas altamente especializadas, de atividades sequenciais e de curto prazo e operaçôes em áreas distantes.

Figueiredo et al. (2007) realizaram estudo sobre as terceirizaçóes e as relações de trabalho na indústria petrolífera offshore no Brasil e consideram que a reestruturação produtiva no setor petrolífero atende aos requisitos de maior produtividade e flexibilidade, alterando significativamente a gestáo do trabalho, seguindo tendência predominante em outros contextos industriais. A terceirização cresceu significativamente na década de 1990, período no qual houve a suspensão dos concursos no âmbito federal e a Petrobras, como empresa pública teve vedada a possibilidade de renovação do seu quadro de pessoal, com redução do efetivo de trabalhadores coincidindo com o período em que houve constante crescimento da produção.

Simultaneamente ocorre a alteraçáo do modelo de organizaçáo gerencial, gerando maior autonomia com a divisão da empresa em unidades de negócios de apoio e corporativas, ampliando a terceirização nas diversas etapas do processo produtivo, inclusive de operação, produção e manutenção. Os autores apontam ainda significativas diferenças de qualificação, treinamento e remuneração entre os efetivos e os terceirizados neste período.

Portanto, atentos aos diferentes contextos, as alteraçóes no mundo do trabalho da indústria do petróleo, seguem as tendências que estão em curso na atualidade, tratando-se de um processo heterogêneo, fragmentado e complexo, como ressaltam Antunes e Alves (2004). Entre as principais mudanças no mundo do trabalho destacam a sua desregulamentação, a informalidade e a terceirização, a redução do proletariado estável, aumento da precarização, ampliação do desemprego estrutural e do trabalho feminino com remuneraçáo inferior ao masculino, a expansáo do setor serviços subordinada à lógica e racionalidade do mercado, a exclusão dos jovens e trabalhadores considerados idosos, bem como a inclusão precoce de crianças, e a expansão do" terceiro setor", como forma alternativa de ocupação.

Há ainda uma última tendência pontuada por estes autores que se relaciona muito bem com a atividade do segmento petrolífero offshore, que é a configuração do mundo do trabalho cada vez mais transnacional. Da mesma forma em que 
ocorreu a transnacionalização do capital, há também um "complexo processo de ampliação das fronteiras no interior do mundo do trabalho", desenvolvendo uma classe trabalhadora que "mescla sua dimensão local, regional, nacional com a esfera internacional” (Antunes \& Alves, 2004, p. 341).

O trabalho offshore no setor petrolífero apresenta ainda algumas particularidades, tendo em vista o fluxo contínuo de produção exigido, adotando contratos flexíveis de trabalho. O mais recente acordo coletivo de trabalho (2017/2018) feito pelo Sindicato dos Trabalhadores Offshore do Brasil (sinditoв) e empresas acordantes abrangendo a categoria "empregados que prestam serviço nas plataformas de produção, prospecção e perfuração de petróleo em alto mar”, com abrangência territorial em Macaé, fixaram um regime de 14 dias trabalhados por 14 dias de folga. Algumas empresas utilizam ainda a escala de 21x21 e de 28x28. Os efetivos da Petrobras geralmente cumprem a escala de $14 \times 21$. Durante os dias embarcados, os trabalhadores podem estar submetidos a dois tipos de escala: i) revezamento em turnos de $12 \mathrm{~h}$, que compreende funçôes operacionais realizadas por técnicos de nível médio; ii) a de sobreaviso, exercido por supervisores e profissionais de nível superior.

Essa peculiaridade do trabalho offshore permite que os empregados morem em locais mais distantes do que seria possível se o deslocamento para o trabalho fosse diário, como a maioria das ofertas de emprego nos mais diferentes segmentos e este fato é contemplado nos acordos coletivos da categoria. Chama atenção ainda nos acordos coletivos dos trabalhadores offshore a importância dada para a qualificação e formação profissional, que ocorrendo fora do horário normal de trabalho é remunerada.

O segmento upstream e suas especificidades aliado às significativas receitas provenientes das compensações financeiras pela produção de óleo e gás na Bacia de Campos permitiram nítidas mudanças na organização do espaço regional. A atração exercida pelos empregos assalariados, acesso ao consumo e possibilidade de ascensão social estimularam a migração de trabalhadores para os municípios produtores de petróleo, contrastando com a tendência anterior caracterizada por um esvaziamento demográfico fruto da decadência das atividades econômicas tradicionais. Produziu ainda um intenso movimento pendular da populaçáo para trabalho e estudo, conforme apontam os estudos de Souza e Terra (2015); Souza, Terra e Campos (2015).

Tudo isso possibilitou um incremento no mercado imobiliário dos municípios litorâneos. Campos dos Goytacazes, por exemplo, é um município que cresceu com uma histórica concentração de terra e capital, dispondo de um seleto grupo de empresários bem-sucedidos que eram proprietários de uma significativa quantidade de imóveis, especialmente na área central. Embora esse cenário estivesse presente desde sua fundação, a nova conjuntura econômica da economia petrolífera aliada ao anúncio das obras do Complexo Logístico, Industrial e Portuário do Açu, no município vizinho de São João da Barra ampliaram sobremaneira a produção imobiliária e destinaram à indústria da construção civil um relevante papel na geração de empregos na região. Dados da Rais/Mte revelam que em 2000, Campos dos Goytacazes tinha 3.233 trabalhadores formais na construção civil, tendo crescido 
para 8.091 em 2010, um crescimento de cerca de 150\%. São João da Barra tinha em 2000 apenas 111 empregos formais na construção civil e em 2010 alcançou 3.583, reflexo em grande parte das obras de construção do Porto, um crescimento de $3.128 \%$. Macaé apresentou um crescimento de empregos na construção civil em torno de $70 \%$, bem inferior a Rio das Ostras, que apresentou um crescimento de 580\% no número de empregos formais na construção civil. Um número significativo de trabalhadores de Macaé reside em Rio das Ostras conforme apontam os estudos sobre pendularidade de Souza e Terra (2015).

Campos dos Goytacazes apesar de não ser sede das instalaçôes das empresas petrolíferas e parapetrolíferas mas por ter sido beneficiada por uma significativa e crescente receita proveniente dos royalties e participaçóes especiais apresentou uma expansão de elevada magnitude da "verticalização", em especial no centro urbano e arredores. O processo de verticalização se concentrou especialmente na Av. Pelinca e adjacências, em especial áreas até então de residências unifamiliares das camadas de mais alta renda. Esse processo impactou a estrutura urbana, sobrecarregando as redes viárias, de água e esgoto e aumentando significativamente a densidade demográfica na área, além, de ter se transformado em um novo subcentro urbano devido ao crescimento das atividades comerciais, financeiras e de serviços em bairros até então tipicamente residenciais.

Conforme destaca Faria (2005):

O processo de verticalização, observado principalmente nas áreas centrais e adjacências, revela de um lado a permanência do alto valor (simbólico e econômico) destes espaços, pela presença de edifícios residenciais para as camadas de alta e média alta renda, de serviços, comércios mais sofisticados e shopping centers, e de outro a permanência da velha configuração espacial da cidade de Campos marcada pela oposiçáo centro-periferia. (p. 4798)

Moniè (2003) destaca que as atividades petrolíferas e parapetrolíferas na região impactaram mais os municípios pelo crescimento demográfico do que pelos reais impactos na estrutura produtiva dos mesmos:

O processo de industrializaçáo/urbanizaçáo reorganiza a estrutura produtiva e o espaço regional, em detrimento do interior estagnado e em benefício dos municípios costeiros que recebem os maiores fluxos de investimentos produtivos, recursos financeiros e trabalhadores. No entanto, este movimento não afeta o litoral de forma homogênea. A cidade de Macaé, por abrigar a totalidade das instalações terrestres da indústria petrolífera, sofre sem dúvida os maiores efeitos da reestruturação em curso. (pp. 276-277)

Terra, Oliveira e Givisiez (2012) calcularam o perfil da especialização por meio do Quociente Locacional (QL) e reestruturação por meio do Coeficiente de Reestruturação $(\text { стј })^{1}$ da mesorregião Norte Fluminense e das microrregióes de Campos dos Goytacazes e Macaé, com base nos dados da Rais/mte e os dados revelaram que a base econômica tradicional encontra-se em franco esgotamento,

1 A metodologia de cálculo do QL e CTJ, bem como todos os indicadores calculados para os 25 subsetores desagregados podem ser obtidos e esclarecidos em Terra, Oliveira e Givisiez (2012). 
enquanto a indústria extrativa mineral e os ramos industriais que compóem sua cadeia produtiva encontram-se em crescimento no período analisado pelos autores que foi de 1985 a 2010.

Essa reestruturação se refletiu no aumento da demanda por mão de obra de diferentes qualificaçóes, difícil de ser suprida apenas com a mão de obra local, principalmente se considerarmos a necessidade de transferência intersetorial de mão de obra entre dois segmentos táo distintos do mercado de trabalho. Grande parcela desta demanda foi suprida através das migraçóes internas (inter e intraestaduais) e internacionais e, também, pelos movimentos pendulares.

\section{Consideraçóes teóricas sobre a relação entre migraçáo, pendularidade e distribuiçáo espacial dos postos de trabalho}

A relação entre trabalho e migração vem sendo exaustivamente considerada nas teorias sobre os determinantes dos movimentos migratórios. Na primeira, e mais clássica, Ravenstein (1980), utilizando o Censo do Reino Unido, realizado em 1871, apontou haver uma relaçáo direta entre a melhoria dos meios de transporte e comunicação, a crescente escolarização dos trabalhadores e as migraçóes internas por motivo trabalho (grifo nosso), ressaltando que as pessoas que migram a longas distâncias se dirigem, preferencialmente, para grandes centros comerciais ou industriais. Para o autor, o motivo econômico - possibilidades de emprego- é o principal determinante dos movimentos migratórios.

Everett Lee (1980), relaciona as migraçóes com o processo de industrializaçáo e modernização econômica, opinião esta compartilhada por Singer (1980). Ambos admitem que a industrialização -concentrada devido a ganhos locacionais e de escala- acirra as desigualdades regionais, criando oportunidades de emprego nas áreas mais dinâmicas, que se tornam áreas de atração populacional; enquanto as áreas menos dinâmicas passam a constituir áreas de expulsão. Singer (1980) considera, ainda, que as migraçóes constituem um mero mecanismo de redistribuição espacial da população, necessário para garantir a continuidade do processo de reprodução do capital e que resultam de dois fatores de naturezas distintas: (i) fatores de mudança e (ii) fatores de estagnação.

Segundo o autor, quando a migração campo-cidade é provocada pelos fatores de mudança - decorrentes da introdução de relaçóes capitalistas de produção na agricultura, aumentando a produtividade marginal do trabalho- os trabalhadores expulsos da área rural são rapidamente absorvidos pelo setor industrial moderno, aumentando, inclusive, a demanda agregada por produtos industrializados, o que beneficia o fluxo circular da renda e da produção. Quando a migração campo-cidade é provocada por fatores de estagnaçáo -que se manifestam pelo excesso de oferta de mão de obra em relação à demanda por mão de obra, nas áreas rurais- seus efeitos são perversos, para a classe trabalhadora: aqueles que permanecem na área rural têm suas condiçōes de vida significativamente deterioradas, dada a elevação dos preços relativos; o mercado de trabalho urbano absorve apenas parcela dos imigrantes, principalmente nos setores de serviços domésticos, porque, em geral, são trabalhadores de baixa qualificação. o centro urbano, a maioria dos migrantes acaba vivendo 
à margem da divisão social do trabalho e reproduzem nas cidades alguns traços da economia de subsistência. Mas ainda assim, as migraçóes continuam funcionais do ponto de vista do desenvolvimento capitalista, uma vez que nas cidades os migrantes -desempregados/subempregados- contribuem para a formação do exército industrial de reserva e, dessa forma, ajudam a manter baixos os salários da classe trabalhadora.

Sjaastad (1980), por sua vez, trata a migraçáo como um investimento em capital humano e admite que a migração apesar de implicar em custos deve render retornos ao migrante. Para o autor, um indivíduo migra quando espera auferir, no destino, uma renda real relativamente mais alta do que aquela recebida na origem.

Todaro (1980), admite, em caso de reestruturação produtiva, a transferência intersetorial de mão de obra, do setor rural para o setor urbano, por exemplo. Mas admite que esta transferência se dá em duas etapas: no primeiro momento os trabalhadores rurais não qualificados se inserem no setor urbano tradicional, composto por atividades que exigem baixa qualificação e onde a produtividade marginal do trabalho é baixa. Alguns migrantes podem, inclusive, permanecerem desempregados, subempregados e empregados no setor informal da economia urbana. Porém acredita que, mais cedo ou mais tarde todos os migrantes serão incorporados ao setor urbano moderno, que exige um profissional mais qualificado, com produtividade mais elevada e que, portanto, recebe maiores salários.

Gino Germani (1971) não nega a importância dos fatores econômicos que influenciam a decisão de migrar, mas afirma que apenas estes fatores são insuficientes para que a migração se efetive. Para ele, se por um lado deve haver desestabilização da sociedade tradicional, por outro lado, os indivíduos devem estar socialmente mobilizados -através dos meios de comunicação de massa, das redes sociais ou mesmo através do contato com a economia moderna- e atraídos pela sociedade moderna, para que a migração ocorra. Sendo assim, a migração rural-urbana é entendida como um processo social e se insere em um contexto de amplas mudanças sociais, culturais e econômicas. Nessa concepção teórica, as migrações são necessárias e funcionais para a modernização da sociedade dos países em desenvolvimento.

Bailey (1993) considera que as migraçôes constituem um processo de aprendizado e que muitos indivíduos migram porque respondem de forma eficiente aos sinais - positivos ou negativos- do mercado de trabalho. Segundo o autor, para avaliarmos se a migração está ocorrendo em função das respostas eficientes dos indivíduos ao mercado de trabalho ou em resposta a fatores de seletividade, devemos analisar as características e a forma de operação do mercado de trabalho. Segundo o autor, nem todos os indivíduos que se encontram desempregados migram, pois os movimentos migratórios implicam em custos monetários muitas vezes não suportado pelo indivíduo, em sua condiçáo de desempregado; outro fator que pode inibir a migração é crença na possibilidade de recontratação.

Segundo Offe (1989), essa teoria de que a mão de obra imigrante -ou mesmo a dos naturais- empregada ou subempregada formam um exército industrial de reserva para a reprodução capitalista não se sustenta, devido, "entre outros fatores, ao caráter crescentemente "heterogêneo" do trabalho social. Por detrás deste argumento está não apenas a defasagem entre a qualificação/especialização dos 
trabalhadores e o desenvolvimento científico-tecnológico, mas sobretudo o uso cada vez maior de tecnologias intensivas em capital, nos processos produtivos.

Ainda que Singer (1980) considere, quando trabalha com a migração decorrente dos fatores de mudança, a possibilidade de rápida realocação intersetorial da mão de obra rural no mercado de trabalho urbano, na realidade a transferência de mão de obra entre setores da economia não se dá com tanta facilidade e para muitos trabalhadores ela sequer acontece; por detrás disso está a diferente qualificação exigida pelos diferentes setores da economia com um mercado de trabalho cada vez mais segmentado.

Patarra (2006, p.11), analisando as migraçóes internacionais considera que "migration is decentralized, temporary, circular, responsive, with calculated risks, conflict generator, global and regulated" e que a compreensão das migraçóes, na atualidade, passa, dentre outros fatores, pela compreensão da teoria do mercado dual de trabalho. Para Kovács (2006, p. 43), o mundo do trabalho tende para o dualismo estando, de um lado, "a elite qualificada detentora de competências-chave exigidas pelo trabalho high-tech, com acesso ao emprego bem pago, estável e garantido e, do outro lado, situa-se a massa de trabalhadores sujeita ao trabalho incerto, mal pago e socialmente degradado".

Jannuzzi (1999), ao discutir a relação entre mobilidade social e migração, considera que, para muitos autores, as intensas migraçóes internas, verificadas no Brasil nos anos 1950, 1960 e 1970, indubitavelmente relacionadas ao processo de industrialização, significaram, para muitos indivíduos, uma mobilidade social ascendente, por proporcionar-lhes uma melhor inserção sócio ocupacional no mercado de trabalho permitindo que, naquele momento, ocorresse uma redistribuiçáo setorial da força de trabalho, no Brasil, ressaltando-se que se por um lado parte dessa mão de obra foi absorvida, no meio urbano, pela indústria, propriamente dita, por outro lado, parte da máo de obra foi absorvida pelo setor urbano tradicional, como aponta Todaro (1980).

A imperfeição na transferência intersetorial de mão de obra também foi também apontada por Oliveira e Piccinini (2011). Se consideramos a teoria da segmentação, a qual afirma que "o mercado de trabalho não é um único espaço competitivo em que todos os postos de trabalho estariam igualmente disponíveis a todos os trabalhadores, mas sim um conjunto de segmentos que não competem entre si" (Oliveira \& Piccinini, 2011, p. 1522). Ainda segundo os autores, "há múltiplos mercados de trabalho que se formam a partir da diversidade de atividades profissionais (...) além da profissão, a localização geográfica dos empregos e da máo de obra, os graus de qualificação exigidos, as delimitaçóes etárias multiplicam o número de mercados de trabalho que se justapóem" (p. 1523).

Está claro que não podemos conceber o mercado de trabalho como um todo homogêneo e, portanto, que a transferência intersetorial dá-se sem qualquer barreira. Na realidade, o mercado de trabalho é composto por "um conjunto de segmentos que não competem entre si” (Oliveira \& Piccinini, 2011, p. 1522) e as peculiaridades de cada segmento do mercado de trabalho torna possível a verificação de um aparente -mas falso- paradoxo: a ocorrência de elevado nível de desemprego simultaneamente ao aumento da procura por máo de obra no mercado de trabalho. 
A questão é que na realidade há uma série de (fortes) barreiras que tornam praticamente impossível a transferência intersetorial para a maior parcela de mão de obra disponível. Dentre elas podem-se mencionar informaçóes imperfeitas, mudança nas açóes das empresas para recrutamento e seleção de mão de obra (importância crescente do papel das redes de relacionamento interpessoais e dos concursos); e atributos (como escolaridade/qualificação/experiência, idade, gênero, etnia, dentre outros) exigidos pelos diferentes segmentos do mercado de trabalho; o nível das remuneraçóes; regras institucionais, dentre outros (Oliveira \& Piccinini, 2011). Sendo assim, a competição dá-se no interior de cada um dos segmentos/ramos do mercado de trabalho. Apenas alguns poucos trabalhadores superaram as barreiras e se inserem em outro segmento.

Por outro lado, Jannuzzi (1999) relativiza a relação entre mobilidade espacial e social, chamando nossa atenção para o fato de que na realidade a mobilidade social foi, também para a grande maioria dos migrantes, apenas de curta distância (se comparado à ocupação do pai e à ocupação do próprio indivíduo no momento anterior à migraçáo) tendo em vista o fato de que ela se deu, predominantemente, para categorias ocupacionais contíguas. Considera, ainda, que parte do que se identifica como mobilidade deve-se, na realidade, à escala ocupacional adotada pelos pesquisadores, e pondera, que é difícil considerar como mobilidade social a alternância entre a condição de boia-fria, no campo, para biscateiro, na cidade. Para muitos, o êxodo rural implicou, inclusive, em perda de qualidade de vida. Em relação a esta questão, Brito (2009, p.16) considera que "as 'externalidades positivas' das grandes cidades, das regióes metropolitanas em particular, que tanto atraíam os migrantes, segundo as teorias econômicas, foram superadas pelas 'externalidades negativas', comprometendo a esperança do migrante de traduzir em realidade a sua ilusão de melhorar de vida".

A importância do setor de serviços como área de absorção da mão de obra não absorvida pelo setor secundário foi também apontada por Antunes e Alves (2004):

É perceptível também, particularmente nas últimas décadas do século xx, uma significativa expansão dos assalariados médios no setor de serviços, que inicialmente incorporou parcelas significativas de trabalhadores expulsos do mundo produtivo industrial, como resultado do amplo processo de reestruturação produtiva, das políticas neoliberais e do cenário de desindustrialização e privatização. (p. 338)

Martine (1980), também relativiza essa relaçâo na medida em que considera que nas pesquisas sobre os movimentos migratórios as informaçóes referem-se aos sobreviventes à reemigração e que as migraçóes são extremamente seletivas segundo os fatores socioeconômicos. Desta maneira, captam-se apenas os indivíduos 'sobreviventes', em tese os mais capacitados; os menos capacitados reemigram, para outras localidades onde estáo sujeitos a novos processos de seletividade.

Apesar destas questôes, Jannuzzi (1999) admite que para um considerável número de migrantes, as migraçóes dos anos 1950, 1960 e 1970, implicaram em ascensão social. Por outro lado, considera que com a crise econômica dos anos 1980, e também dos anos 1990, a migração passou a representar, para muitos indivíduos, 
antes uma estratégia de sobrevivência e manutenção de posição na estrutura social, do que de ascensão.

Segundo Baeninger (2000, p. 1), estamos experimentando, no Brasil uma expansão dos espaços da migração, "com a incorporação de novas áreas de absorção populacional" devido, de um lado, ao processo de esgotamento das fronteiras agrícolas e, de outro, ao processo de desconcentraçáo relativa da atividade industrial, em direção a áreas interioranas de alguns estados. Ressalta-se que a desconcentração industrial além de tornar algumas áreas mais atrativas para os imigrantes aumenta seu poder de retenção sobre a população residente. Nesse sentido, considera que para torna-se necessário compreender as dinâmicas migratórias intra-regionais, "não tanto pela importância numérica que se impóe, mas pelas transformaçóes que se pode captar no fenômeno migratório nesses espaços".

Cunha (2012), observa que a migraçáo deve ser pensada em duas perspectivas: como componente demográfico determinante do tamanho, da estrutura e da distribuição espacial da população, mas sobretudo como um processo social que esteve presente, através de suas diversas modalidades, em todo o processo de desenvolvimento econômico e social brasileiro. Segundo o autor, no momento atual, as migraçóes no Brasil não apenas continuam refletindo algumas características histórias das migraçóes internas no país (movimentos rurais-urbanos; movimentos intrametropolitanos, dentre outros), como vem "apresentando novas feiçóes, fenômenos, condicionantes e consequências” (p. 35), dentre as quais destacamos, no âmbito deste estudo, as migraçóes internas no estado do Rio de Janeiro, em direção aos municípios produtores de petróleo da Bacia de Campos, assim como as mudanças de residência entre os próprios municípios produtores.

Uma outra estratégia de sobrevivência e de manutenção de posição na estrutura social relativa que vem sendo a cada dia mais utilizada pelas populaçóes, são os movimentos pendulares, compreendidos como os movimentos da vida quotidiana, nesse caso específico, na mobilidade entre residência -local de trabalho-residência; observe que, diferentemente das migraçóes, nesse caso não há mudança do local de domicílio.

No Brasil, informaçóes sobre os movimentos pendulares são relativamente escassas. Uma primeira indagação sobre a mobilidade por trabalho entre municípios distintos foi realizada em 1970 e mantida no Censo Demográfico de 1980. A questão sobre pendularidade foi suprimida no Censo de 1991, mas reincorporada no Censo de 2000. O Censo de 2010, náo apenas manteve o quesito, mas o aperfeiçoou, permitindo pesquisas mais aprofundadas na área.

Apesar da lacuna informacional sobre a mobilidade pendular, alguns pesquisadores -Oliveira (2006); Souza e Terra (2015)-reconhecem que estes movimentos, antes bastante restritos às áreas metropolitanas, na atualidade estáo aumentando em volume e distância, extrapolando os contornos metropolitanos. A pendularidade é uma realidade entre municípios interioranos pertencentes ou náo a um mesmo aglomerado urbano. Nesse sentido, pode-se dizer que a pendularidade reflete, para um número cada vez maior de pessoas, a dissociação entre o local de residência e o de moradia e, indubitavelmente, o seu incremento deve-se ao avanço dos meios de 
transporte, ao aperfeiçoamento da infraestrutura viária de muitas cidades e regiōes e do sistema urbano de circulação de passageiros.

Antunes e Alves (2004) consideram que com a internacionalização e transnacionalização do capital, com as novas formas de contratação, a ampliação do conceito e as novas relaçóes de trabalho, as fronteiras do mundo do trabalho também se ampliaram. Nas palavras dos autores, "a classe trabalhadora se conforma mundialmente" (p. 341). Consequência disso é o aumento da competitividade no mundo do trabalho: em muitos segmentos a concorrência por uma vaga de emprego passa a ser internacional. Segundo Oliveira e Piccinini (2011),

O mercado de trabalho pode ser entendido como o espaço de lutas entre diferentes agentes (indivíduos, organizaçóes, órgãos de regulação, países, etc.) que se constitui historicamente pela incorporação de regras sociais que orientam as estratégias que os mesmos utilizam no interior deste mesmo campo. (p. 1532)

\section{Migraçóes, pendularidades e mercado trabalho no segmento upstream da indústria do petróleo na Bacia de Campos}

Como se mencionou, na segunda seçáo deste artigo, o norte fluminense passou, a partir de meados dos anos 1970, por uma intensa reestruturaçáo produtiva com a instalação da indústria petrolífera, significativamente diversa das instalaçôes industriais até então verificadas. Nesse aspecto é preciso considerar, pelos vários motivos que servem como barreiras à transferência intersetorial de máo de obra - apontados por Offe (1989), Singer (1980) e Oliveira e Piccinini (2011), grande parcela da mão de obra local não foi absorvida, por falta de qualificação profissional adequada, para indústria extrativa mineral que se instalava. Ao mesmo tempo a região tornava-se uma nova área de atração populacional, no interior do Estado do Rio de Janeiro, considerando-se que as oportunidades de trabalho constituem -como vimos em Ravenstein (1980), Everett Lee (1980) e Singer (1980), por exemplo- o principal motivo pelo qual os indivíduos migram.

Parte da mão de obra desempregada na indústria salineira e na indústria sucroalcooleira foi absorvida pelo setor de comércio e serviços, fomentados em grande medida pelo próprio desenvolvimento da indústria petrolífera. Outra parcela da mão de obra não apenas não foi absorvida como nem ao menos chegou a constituir exército industrial de reserva para aquele segmento do mercado de trabalho. O novo mercado de trabalho da indústria petrolífera necessitava de mão de obra qualificada e as migraçóes -internas e internacionais-, assim como os movimentos pendulares, foram imprescindíveis para cobrir esta lacuna. Como ressalta Cunha (2012), as migraçóes alteraram as dinâmicas demográficas dos municípios produtores de petróleo, serviram como um importante mecanismo de redistribuição espacial da população em direção a esta área e também internamente e, juntamente com os movimentos pendulares, revelaram-se um processo indispensável para o desenvolvimento socioeconômico da Bacia de Campos.

$\mathrm{Na}$ Tabela 1 apresentam-se informações referentes às migraçóes interestaduais e intraestaduais, para os municípios selecionados -Arraial do Cabo, Armação dos 
Búzios, Cabo Frio, Carapebus, Campos dos Goytacazes, Casimiro de Abreu, Macaé, Quissamã, Rio das Ostras e São João da Barra- referentes ao período 2005-2010².

Observe que em todos estes municípios, os saldos migratórios interestaduais apresentaram-se positivos, o que os classifica como receptores líquidos de imigrantes -saldo migratório de 20.323 indivíduos, para o agregado- provenientes de outras unidades da federação.

Como era de se esperar, a migração intraestadual é, em volume, significativamente superior: através dos microdados censitários de 2010, entre 2005-2010, estimou-se, para o conjunto dos municípios selecionados, um total de 123.888 imigrantes, 74.241 emigrantes e um saldo migratório positivo de 49.647 indivíduos. Com exceção de Campos dos Goytacazes, os demais municípios selecionados não somente atraem imigrantes de outros estados brasileiros, mas, principalmente, de outros municípios fluminenses, ressaltando-se que esses resultados incluem as trocas populacionais entre eles.

Campos dos Goytacazes é um caso ímpar: apesar de se destacar como polo econômico regional é o único, dentre os municípios selecionados, com saldo migratório total negativo, devido às significativas emigraçóes intraestaduais, ressaltando que pesquisas anteriormente realizadas por Souza e Terra (2016) apontam que as maiores perdas populacionais se dão para municípios da própria região Norte, mais especificamente para Macaé e Rio das Ostras.

Analisando, na Tabela 1, os indicadores da migraçáo total, percebe-se que entre 2005-2010 foram bastante significativos os movimentos migratórios envolvendo esses municípios: em termos brutos estamos falando de 241.266 migrantes; e, em termos líquidos, de um ganho populacional de 69.970 pessoas. O maior ganho líquido foi o de Rio das Ostras (30.606 indivíduos), seguido por Cabo Frio (15.595) e Macaé (15.232).

Como se pode notar na Tabela 1 , mesmo sendo área de atração (saldo migratório positivo), são significativos os fluxos emigratórios. Isso ocorre porque, a indústria petrolífera seleciona apenas os indivíduos mais capacitados, enquanto os menos capacitados enxergam na emigração uma estratégia de sobrevivência, dada a possibilidade de empregabilidade em outros mercados de trabalho (Martine, 1980).

Com exceção de Campos dos Goytacazes, as migraçóes aceleraram o crescimento populacional dos demais municípios. Esse 'efeito acelerador', medido pela Taxa Líquida de Migração (тLM) foi da ordem de 28,96\% em Rio das Ostras, 14,42\% em Casimiro de Abreu e 11,64\% em Carapebus. Como se pode observar na Tabela 2, todos estes municípios apresentaram, no período 2000-2010, crescimento populacional acima da média estadual (1,06\% a.a), destacando-se o extraordinário ritmo de crescimento de Rio das Ostras (11,24\% ao ano), Casimiro de Abreu (4,78\%), Macaé (4,55\%) e Carapebus (4,42\%). Segundo Souza e Terra (2017, no prelo), este conjunto de municípios vem se destacando, pelo menos desde os anos 1980, como a principal área de expansão urbana do estado do Rio de Janeiro. 


\begin{tabular}{|c|c|c|c|c|c|c|c|c|c|c|c|c|c|c|}
\hline \multirow{4}{*}{ 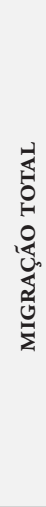 } & $\sum_{H}$ & $\stackrel{\infty}{\sim}$ & $\vec{\infty}$ & $\begin{array}{l}\infty \\
\infty \\
\infty\end{array}$ & & & $\overrightarrow{\mathrm{N}}$ & \begin{tabular}{l}
$\underset{f}{f}$ \\
\multirow{f}{*}{}
\end{tabular} & $\stackrel{\hat{2}}{\hat{n}}$ & 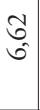 & $\begin{array}{l}0 \\
2 \\
\infty \\
\sim \\
\sim\end{array}$ & $\begin{array}{l}n \\
\infty \\
0 \\
0\end{array}$ & $\stackrel{\sim}{\tilde{\sigma}}$ & 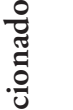 \\
\hline & $\sum_{n}$ & $\begin{array}{l}\text { के } \\
\text { ì }\end{array}$ & $\begin{array}{l}\stackrel{0}{\infty} \\
\infty \\
-\end{array}$ & $\begin{array}{l}n \\
2 \\
i n \\
n\end{array}$ & & & 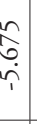 & 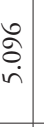 & 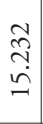 & $\underset{\vec{\sigma}}{\vec{\sim}}$ & $\begin{array}{l}0 \\
\delta \\
0 \\
0 \\
\dot{n}\end{array}$ & 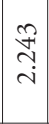 & 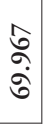 & 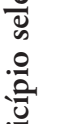 \\
\hline & 피 & $\underset{\sim}{\stackrel{\circ}{\sim}}$ & \begin{tabular}{l}
\multirow{J}{0}{} \\
$\sim$ \\
$i$
\end{tabular} & $\begin{array}{l}2 \\
1 \\
0 \\
2\end{array}$ & & $\hat{\hat{C}}$ & 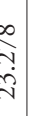 & $\begin{array}{l}\stackrel{\overrightarrow{+}}{\mathrm{i}} \\
\mathrm{i}\end{array}$ & $\begin{array}{l}\hat{n} \\
\frac{n}{2}\end{array}$ & $\widehat{\widehat{~}}$ & $\begin{array}{c}n \\
\Xi \\
0 \\
=\end{array}$ & $\begin{array}{l}\hat{f} \\
\stackrel{f}{+} \\
-1\end{array}$ & $\begin{array}{l}\vec{\pi} \\
\ddot{0} \\
\infty\end{array}$ & $\begin{array}{l}\Xi \\
\Xi \\
\vdots \\
0\end{array}$ \\
\hline & - & 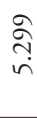 & $\begin{array}{l}\stackrel{8}{\mathscr{H}} \\
\stackrel{+}{+}\end{array}$ & $\mid \begin{array}{l}d \\
z \\
w\end{array}$ & & 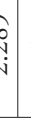 & 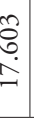 & $\tilde{\kappa}$ & 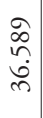 & 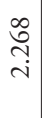 & $\mid \begin{array}{l}2 \\
\hat{\imath} \\
\dot{q} \\
+1\end{array}$ & $\begin{array}{c}\tilde{R} \\
\hat{n} \\
\dot{n}\end{array}$ & $\begin{array}{l}\infty \\
\vdots \\
i \\
\sim \\
n\end{array}$ & 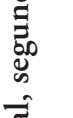 \\
\hline \multirow{4}{*}{ 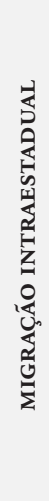 } & $\sum_{H}$ & $\vec{t}$ & $\sqrt{\tilde{\sigma}}$ & $\bar{N}$ & & $\begin{array}{ll}n \\
b \\
b \\
c\end{array}$ & $\begin{array}{l}\vec{F} \\
\overrightarrow{-} \\
\overrightarrow{1}\end{array}$ & $\overrightarrow{\mathfrak{I}}$ & $\begin{array}{l}\infty \\
\hat{\sim}\end{array}$ & $\hat{n}$ & $\left|\begin{array}{l}\overrightarrow{\tilde{J}} \\
\vec{\sim}\end{array}\right|$ & $\mid \begin{array}{l}\infty \\
\sim \\
\sim\end{array}$ & $\underset{f}{\mathbb{f}}$ & $\begin{array}{l}\stackrel{0}{0} \\
0 \\
\stackrel{T}{\Xi}\end{array}$ \\
\hline & $\sum_{m}$ & హ్ర & $\begin{array}{l}\text { ?े } \\
\stackrel{\infty}{-}\end{array}$ & 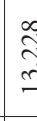 & & 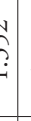 & 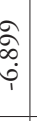 & 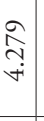 & $\begin{array}{l}\stackrel{\curvearrowright}{\hat{n}} \\
\dot{n}\end{array}$ & $\begin{array}{l}\tilde{O} \\
\stackrel{0}{ } \\
\stackrel{-}{2}\end{array}$ & $\mid \begin{array}{c}\hat{\alpha} \\
\tilde{\sim} \\
\sim \\
\sim\end{array}$ & $\begin{array}{l}\stackrel{\hat{N}}{S} \\
-\end{array}$ & $\begin{array}{c}\text { जै } \\
\stackrel{\vec{q}}{\vec{t}}\end{array}$ & $\begin{array}{l}\stackrel{\mathbb{J}}{\mathscr{J}} \\
\stackrel{\Xi}{\Xi} \\
. \Xi\end{array}$ \\
\hline & س & 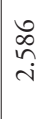 & $\underset{\curvearrowright}{\stackrel{\Omega}{i}}$ & $\begin{array}{l}\tilde{\Xi} \\
\text { I }\end{array}$ & 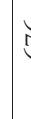 & $\begin{array}{l}0 \\
0 \\
0\end{array}$ & 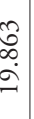 & $\begin{array}{l}\vec{n} \\
\tilde{i}\end{array}$ & $\begin{array}{l}n \\
\hat{\sigma} \\
\infty \\
\infty\end{array}$ & $\widehat{\widehat{\alpha}}$ & $\begin{array}{l}N \\
\hat{\sigma} \\
\dot{a}\end{array}$ & 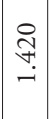 & 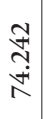 & 胥 \\
\hline & - & 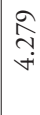 & $\begin{array}{l}\not+ \\
\stackrel{+}{~} \\
\text { iे }\end{array}$ & $\begin{array}{l}a \\
\tilde{m} \\
\text { d }\end{array}$ & & 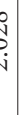 & 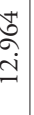 & $\begin{array}{l}\text { ర్రి } \\
\text { }\end{array}$ & $\begin{array}{l}\infty \\
\infty \\
\infty \\
\ddot{\sim} \\
\vec{\lambda}\end{array}$ & $\begin{array}{l}\stackrel{े}{े} \\
\text { i }\end{array}$ & $\mid \begin{array}{c}\hat{\tilde{\sigma}} \\
\stackrel{+}{+} \\
\tilde{f}\end{array}$ & $\underset{\mathcal{F}}{\stackrel{\mathcal{T}}{r}}$ & 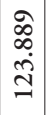 & 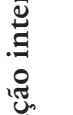 \\
\hline \multirow{4}{*}{ 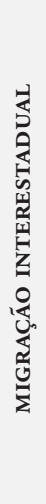 } & $\sum_{H}^{\Sigma}$ & $\underset{\sim}{*}$ & స్ & $\hat{z}$ & & $\begin{array}{c}t_{1} \\
= \\
=\end{array}$ & $\begin{array}{c}0 \\
1 \\
0 \\
0\end{array}$ & $\overrightarrow{\widetilde{v}}$ & $\begin{array}{l}\hat{n} \\
\hat{f}\end{array}$ & $\begin{array}{l}\infty \\
\stackrel{\sim}{\sim}\end{array}$ & $\begin{array}{l}\stackrel{n}{\hat{f}} \\
f^{2}\end{array}$ & $\hat{\approx}$ & $\begin{array}{c}1 \\
\infty \\
-1\end{array}$ & 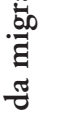 \\
\hline & $\sum_{m}$ & ふ্ & $\infty$ & $\begin{array}{l}\hat{0} \\
\tilde{2}\end{array}$ & & 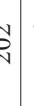 & $\underset{\sim}{\mathbb{Z}}$ & $\vec{\infty}$ & 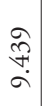 & $\grave{\triangleq}$ & $\begin{array}{l}\vec{\delta} \\
\dot{\sim}\end{array}$ & $\vec{n}$ & 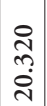 & 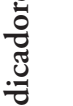 \\
\hline & س & $\underset{\widetilde{U}}{\mathbb{Z}}$ & $\begin{array}{l}n \\
\infty \\
m\end{array}$ & $\stackrel{\overbrace{}}{7}$ & & $\hat{n}$ & 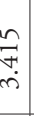 & 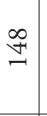 & $\begin{array}{l}\tilde{J} \\
\tilde{n} \\
m\end{array}$ & 0 & $\begin{array}{l}\vec{F} \\
\stackrel{-}{-}\end{array}$ & $\hat{m}$ & 㝘 & $\begin{array}{l}1 \\
\stackrel{1}{0} \\
\stackrel{0}{\pi}\end{array}$ \\
\hline & - & ָิ & ఫ্ & 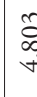 & & $\vec{v}$ & $\begin{array}{c}\widehat{\widehat{\sigma}} \\
\overrightarrow{+}\end{array}$ & $\stackrel{n}{2}$ & $\begin{array}{l}\vec{R} \\
\vec{\jmath} \\
\end{array}$ & $\grave{\triangleq}$ & 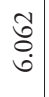 & $\tilde{n}$ & 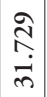 & \\
\hline \multicolumn{2}{|c|}{ 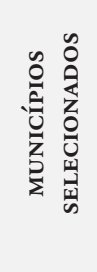 } & 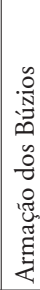 & 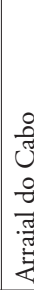 & $\begin{array}{l}\text { 里 } \\
\text { त } \\
\text { तै }\end{array}$ & & & $\begin{array}{l}0 \\
0 \\
y \\
o \\
0 \\
o \\
0 \\
0\end{array}$ & 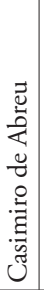 & 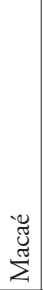 & 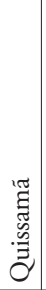 & 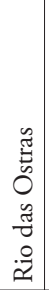 & 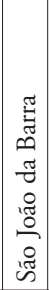 & 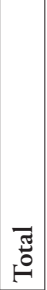 & 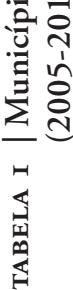 \\
\hline
\end{tabular}




\begin{tabular}{|l|r|r|c|}
\hline \multirow{2}{*}{$\begin{array}{c}\text { MUNICípIOS } \\
\text { SELECIONADOs }\end{array}$} & $\mathbf{2 0 0 0}$ & \multirow{2}{*}{$\begin{array}{c}\text { TAXA DE } \\
\text { CRESCIMENTO }\end{array}$} \\
\cline { 2 - 3 } & 18.204 & $\mathbf{2 0 I 0}$ & 4,23 \\
\hline Armação dos Búzios & 23.877 & 27.560 & 1,50 \\
\hline Arraial do Cabo & 126.828 & 186.227 & 3,92 \\
\hline Cabo Frio & 8.666 & 13.359 & 4,42 \\
\hline Carapebus & 407.168 & 463.731 & 1,31 \\
\hline Campos dos Goytacazes & 22.152 & 35.347 & 4,78 \\
\hline Casimiro de Abreu & 132.461 & 206.728 & 4,55 \\
\hline Macaé & 13.674 & 20.242 & 4,00 \\
\hline Quissamã & 36.419 & 105.676 & 11,24 \\
\hline Rio das Ostras & 27.682 & 32.747 & 1,69 \\
\hline São João da Barra & 817.131 & 1.119 .332 & 3,20 \\
\hline Total & & & \\
\hline
\end{tabular}

TABela 2 | Municípios selecionados - Populaçáo e taxa de crescimento (2000-2010)

FONTE: IBGE - CENSO DEMOGRÁFICO (2OIO)

Como se mencionou anteriormente, além das migrações internas, os movimentos pendulares são também importantes para suprir a carência por mão de obra, no mercado de trabalho. Tendo em vista as peculiaridades que envolvem os contratos de trabalho no segmento upstream da indústria petrolífera, parece-nos mais conveniente adotar como conceito de pendularidade o deslocamento - diário ou não- realizado pelos trabalhadores (porque estamos considerando apenas a mobilidade por motivo trabalho) entre o local de residência e o local de trabalho, sendo que estes se localizam em municípios distintos.

$\mathrm{Na}$ Tabela 3 encontram-se sumarizadas as informaçóes sobre a pendularidade entre os municípios selecionados e outros estados da federação e entre outros municípios fluminenses, incluindo a pendularidade entre eles.

Considerando-se a pendularidade entre os municípios selecionados e outros municípios brasileiros, percebe-se uma entrada de 12.329 trabalhadores (Tabela 3) dentre os quais $7.486(60,75 \%)$ originários em estados da própria regiáo Sudeste, notadamente no Espírito Santo e em Minas Gerais. No entanto, por se tratar de fluxos pendulares, que não envolvem mudança de residência entre a origem e o destino, nos chama a atenção a participação relativa dos nordestinos: 29,72\% dos trabalhadores pendulares interestaduais.

A saída de trabalhadores pendulares dessa regiāo para outros estados brasileiros é pequena, e prevalecem como destino aqueles espacialmente mais próximos. Com exceção de Arraial do Cabo, Carapebus, Casimiro de Abreu e Quissamá, em todos os outros municípios o saldo pendular interestadual é positivo, sendo este relativamente mais elevado em Macaé, que recebe praticamente $75 \%$ dos trabalhadores pendulares interestaduais, e em Campos dos Goytacazes. 


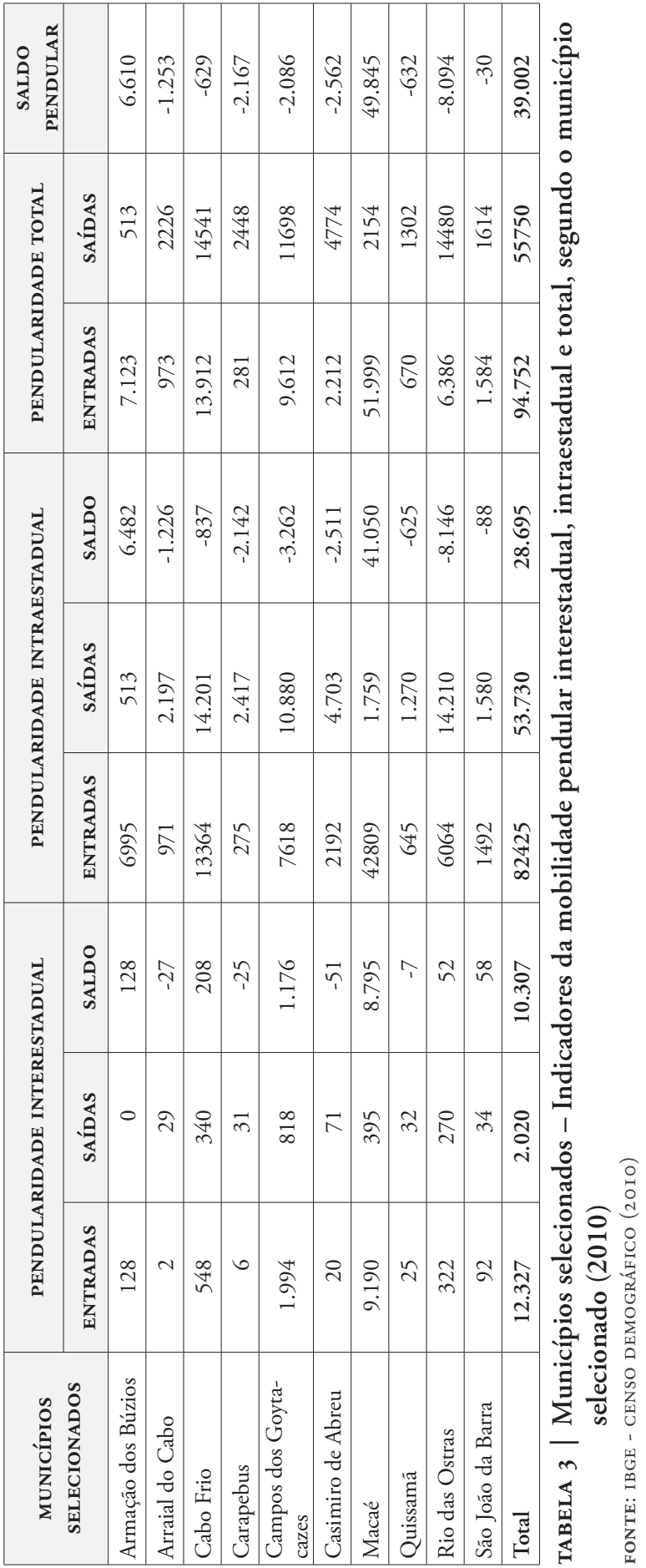


Assim como no caso das migraçóes, os fluxos pendulares intraestaduais são significativamente mais densos: considerando-se esse conjunto de municípios, a pendularidade bruta, em 2010, foi da ordem de 136.155 trabalhadores. Observe, na Tabela 3, que no contexto intraestadual, apenas Macaé e Armação dos Búzios se destacam como áreas de atração tendo o primeiro atraído, em termos líquidos, 41.050 e, o segundo, 6.482 trabalhadores. Nos demais, o saldo pendular é negativo, refletindo a baixa capacidade de absorção/retenção da mão de obra residente por seus respectivos mercados de trabalho. Em termos consolidados, os saldos pendulares positivos também só se verificaram nesses dois municípios. Do total de trabalhadores pendulares, praticamente 55\% eram absorvidos pelo mercado de trabalho de Macaé; $14 \%$ por Cabo Frio; e $10 \%$ por Campos dos Goytacazes. Por outro lado, 26,08\% do total de trabalhadores que saíram desses municípios para trabalhar em outro, originaram-se em Cabo Frio; 25,97\% em Rio das Ostras; e 21\% em Campos dos Goytacazes.

Esses resultados indicam que tanto Macaé quanto Búzios, apesar das diferentes escalas, além de atraírem muitos trabalhadores residentes em outros municípios tem uma grande capacidade de retenção da mão de obra lá residente, isso porque para cada trabalhador que saiu, entraram 24 em Macaé, e 14 em Búzios. Diferentemente, em Cabo Frio, Campos e Rio das Ostras, tanto as entradas quanto as saídas são significativas, sugerindo haver uma seletividade da mão de obra nesses mercados de trabalho, que merece ser mais bem compreendida.

Souza e Terra (2015) desenvolveram um indicador do nível de dependência de um mercado de trabalho em relação à mão de obra exógena ${ }^{3}$, definida como sendo composta pelos imigrantes recentes ${ }^{4}$, excluindo-se o natural que emigrou e retornou para o município de nascimento durante o quinquênio (neste caso a emigração foi compreendida como um investimento em capital humano) e por trabalhadores pendulares ${ }^{5}$. Considerando o indicador ampliado de dependência de mão de obra exógena (Tabela 4), estimado pelo quociente entre o total de imigrantes recentes (exclusive os de retorno para o município de nascimento) somado aos trabalhadores pendulares e o total de trabalhadores $\mathrm{NO}$ município, verificaram que a dependência por mão de obra exógena é relativamente elevada, em todos os municípios selecionados. Em apenas quatro municípios -Quissamá, Campos dos Goytacazes, Arraial do Cabo e Casimiro de Abreu- esse indicador é inferior a 40\%, ou seja, que apenas menos de $40 \%$ da mão de obra ocupada no município é composta por imigrantes recentes ou por trabalhadores pendulares. Em dois municípios -Armação de Búzios e Macaé- a dependência por mão de obra exógena apresentou-se significativamente elevada e da magnitude de $55,4 \%$ e de $59,7 \%$, respectivamente.

$3 \longdiv { \text { A metodologia desenvolvida para a estimativa deste indicador encontra-se detalhada no respectivo } }$ artigo.

4 Aqueles com menos de 10 anos de residência no município de residência atual.

5 Considerando-se a pendularidade em seu sentido mais amplo. 


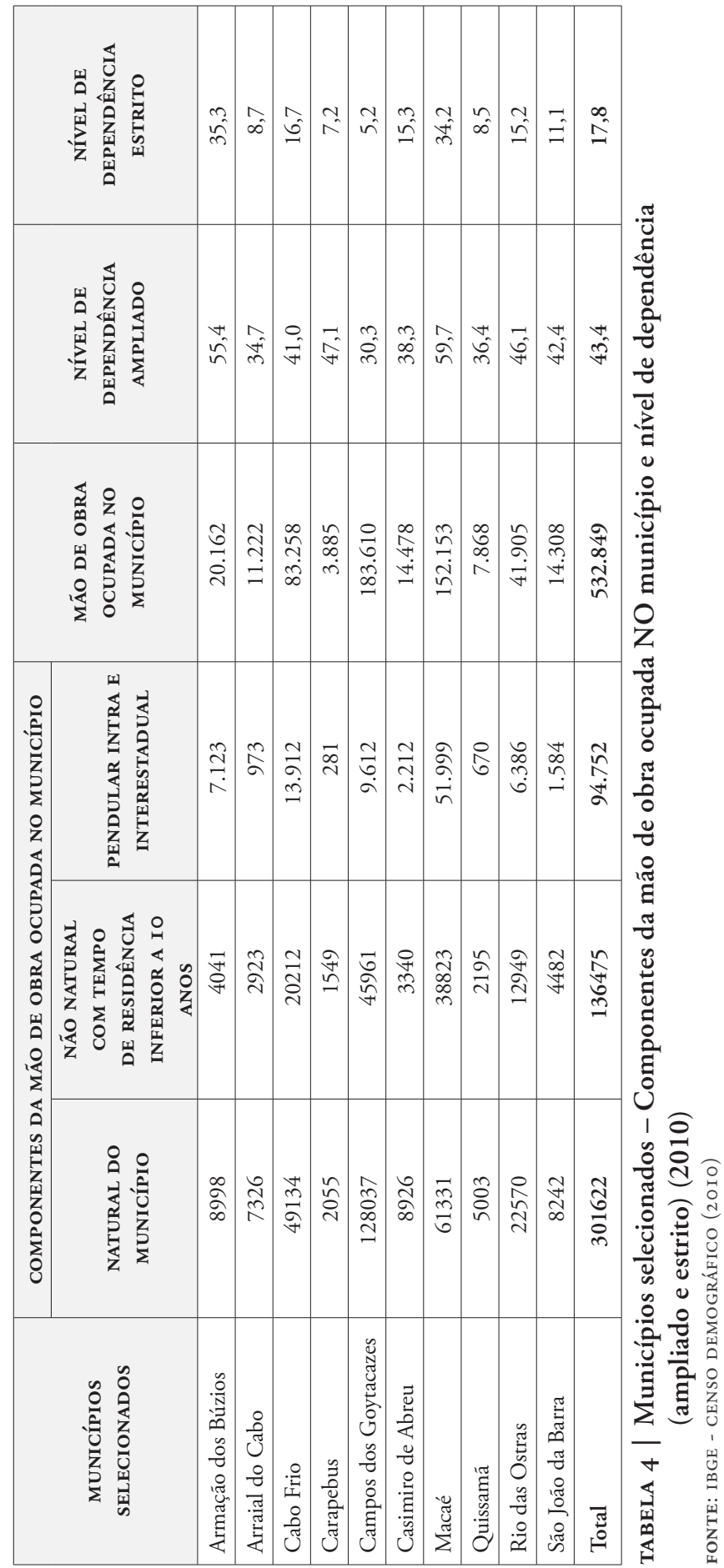


Considerando-se apenas a mão de obra pendular, no numerador, para a estimativa do indicador estrito, percebe-se uma dependência de mão de obra exógena (estrita) de 35,34\% em Armação dos Búzios e de 34,18\% em Macaé (Tabela 4). Observe que a diferença entre o indicador ampliado e estrito se deve aos movimentos migratórios, de onde se conclui que para Búzios e Macaé os dois componentes deste indicador -migração e pendularidade- são praticamente igualmente importantes para suprir a necessidade de máo de obra -mais qualificada- desses mercados de trabalho; e que apesar da pendularidade, antes bastante restrita ao ambiente metropolitano, estar aumentando em áreas interioranas, as migraçôes interestaduais e intraestaduais ainda são fundamentais para a continuidade do processo de reprodução do capital, ainda que não resultem em ascensão social dos trabalhadores migrantes, mas simplesmente os mantenha na estrutura social relativa.

\section{Consideraçóes finais}

O norte fluminense passou, a partir de meados dos anos 1970, por uma intensa reestruturação produtiva, que impactou significativamente o mercado de trabalho que a partir de então não pode sequer ser considerado regional, mas nacional ou, melhor dizendo, internacional.

Em decorrência das várias e, pelo menos no curto prazo, intransponíveis barreiras à transferência intersetorial de mão de obra do setor sucroalcooleiro para o de extração petrolífera, grande parcela dos trabalhadores locais não apenas não pôde de ser absorvida pela indústria extrativa mineral, como sequer chegaram a constituir exército industrial de reserva para a mesma.

$\mathrm{Na}$ década de 1970, as instituiçóes de ensino superior da região poucas e com formaçóes mais nas áreas de ciências humanas e sociais aplicadas -licenciaturas, medicina, direito, dentre outros-. Os cursos voltados para a qualificação da mão de obra demandada pela indústria petrolífera -cursos de engenharias- chegaram bem mais tarde, já nos anos 1990, com a criação da Universidade Estadual do Norte Fluminense Darcy Ribeiro (UENF), no município de Campos dos Goytacazes. Antes da Uenf, a formação técnica era realizada pela Escola Técnica Federal de Campos, hoje Instituto Federal Fluminense. Dada a escassez de mão de obra qualificada e a impossibilidade de treinar a máo de obra disponível, no curto prazo, as migraçóes -internas e internacionais- apresentavam-se como uma importante estratégia para suprir as necessidades da empresa e os imigrantes foram atraídos pelas possibilidades de emprego, pelos altos salários, pelas especificidades dos contratos de trabalho e, inclusive, pela qualidade de vida propiciada pela área litorânea.

Paralelamente, verificaram-se iniciativas privadas e do setor público no sentido de criar instituiçóes de ensino visando melhor capacitação dos trabalhadores. Inicialmente tais instituiçóes concentraram-se em Campos dos Goytacazes mas, atualmente muitos municípios da Bacia de Campos contam com renomadas instituiçôes de ensino técnico profissionalizante e de ensino superior. No entanto, as migraçóes internas e internacionais permanecem como importante estratégia para a ocupaçáo 
destes postos de trabalho, uma vez que se trata de um mercado de trabalho global, que atrai mão de obra de várias regiôes do país e, inclusive, de outros países.

Além das migraçóes, os movimentos pendulares também constituem uma importante estratégia para as empresas ocuparem os postos de trabalho oferecidos e para os trabalhadores, que não precisam mudar seu local de residência ou têm a possibilidade de residir em áreas onde o custo de vida é mais barato. Esses movimentos são facilitados com o desenvolvimento do sistema de transportes e comunicaçôes e estão se tornando cada vez mais volumosos em áreas interioranas, como é o caso dos municípios da Bacia de Campos, aqui estudados.

O fato é que a indústria petrolífera, ainda hoje, depende de mão de obra exógena, ou seja, de mão de obra migrante e pendular, ressaltando-se que há pendulares residentes em outros estados brasileiros (inclusive na região Norte e Nordeste) e, inclusive, em outros países. Estes movimentos só são possíveis tendo em vista as especificidades dos regimes de contratação no segmento upstream da indústria petrolífera, não menosprezando o papel da modernização e redução dos preços relativos do transporte, que reduzem os custos destes movimentos para o trabalhador e/ou para a própria empresa.

\section{Agradecimento}

As autoras agradecem ao CNPQ (Conselho Nacional de Desenvolvimento Científico e Tecnológico), à faperj (Fundação de Amparo à Pesquisa do Estado do Rio de Janeiro), a CAPEs (Coordenação de Aperfeiçoamento de Pessoal de Nível Superior) e ao Projeto Territórios do Petróleo (Projeto de Educação Ambiental Desenvolvido pela Petrobras, ibama e uenf, nos municípios produtores de Petróleo da Bacia de Campos) pelo apoio financeiro concedido em projetos que subsidiaram o financiamento deste trabalho.

\section{Referências bibliográficas}

Acordo Coletivo de Trabalho (2017/2017). Sindicato dos Trabalhadores Offshore do Brasil (SINDITOB). Em https://www.sinditob.org/arqs/acordo_coletivo/ original/201803260820110000002610.pdf

Antunes, R. \& Alves, G. (2004). As mutaçôes no mundo do trabalho na era da mundialização do capital. Educação e Sociedade, 25(87), 335-351. Em http://www.scielo.br/pdf/es/ v25n87/21460.pdf

Baeninger, R. (2000). Novos espaços da migraçáo no Brasil: Anos 80 e 90. Anais do XII Encontro Nacional de Estudos Populacionais. Caxambú, Minas Gerais: Associação Brasileira de Estudos Populacionais (ABEP). Em http://www.abep.org.br/publicacoes/index.php/ anais/article/view/980/945

Bailey, A. J. (1993). Migration history, migration behavior and selectivity. The Annals of Region Science, 4(27), 315-326. https://doi.org/10.1007/BF01583571 
Brito, F. (2009). As migrações internas no Brasil: um ensaio sobre os desafios teóricos recentes. Texto para Discussão, 366. Belo Horizonte: Universidade Federal de Minas Gerais (UfMG)/Centro de Desenvolvimento e Planejamento Regional (Cedeplar). Em https:// bit.ly/2KKxfq3

Cunha, J. M. (2012). Retratos da mobilidade espacial no Brasil: os censos demográficos como fonte de dados. Revista Interdisciplinar da Mobilidade Humana, 20(39), 29-50. Em http://remhu.csem.org.br/index.php/remhu/article/view/330/297

Decreto 2.705 de 3 de agosto de 1998. Define critérios para cálculo e cobrança das participaçōes governamentais de que trata a Lei $\mathrm{n}^{\circ}$ 9.478, de 6 de agosto de 1997, aplicáveis às atividades de exploraçáo, desenvolvimento e produção de petróleo e gás natural, e dá outras providências. Brasília, DF. Em http://www.planalto.gov.br/ccivil_03/decreto/ D2705.htm

Faria, T. J. P. (2005). Configuração do espaço urbano da cidade de Campos dos Goytacazes, após 1950: novas centralidades, velhas estruturas. Anais do X Encontro de Geógrafos da América Latina. São Paulo: Universidade de São Paulo (UsP). Em https://bit. ly/2R6Ycp2

Figueiredo, M., Alvarez, D., Athayde, M., Suárez, J. D. \& Pereira, R. (2007). Reestruturação produtiva, terceirização e relaçóes de trabalho na indústria petrolífera offshore da Bacia de Campos, RJ. Gestão e Produção, 14(1), 55-68. Em http://www.scielo.br/pdf/gp/ v14n1/05.pdf

George, M. (1980). Adaptação dos migrantes ou sobrevivência dos mais fortes? In H. A. Moura (coord.), Migraçâa interna: textos selecionados, 2 (pp. 949-974). Fortaleza: Banco do Nordeste do Brasil/Escritório Técnico de Estudos Econômicos do Nordeste (BNB/ ETENE).

Germani, G. (1971). Sociología de la Modernización: estudios teóricos, metodológicos y aplicados a América Latina. Psicología Social y Sociología, 36, Buenos Aires: Paidós.

Instituto Brasileiro de Geografia e Estatística (IBGE). (2010). Censo Demográfico. Característica da População e dos domicílios. Em http//www.ibge.gov.br/home/

Jannuzzi, P. M. (1999). Mobilidade social e migração no Brasil: revisão bibliográfica e elementos empíricos para análise. Revista Brasileira de Estudos Populacionais, 16(1/2), 55-82. Em https://www.rebep.org.br/revista/issue/view/27/showToc

Kovács, I. (2006). Novas formas de organização do trabalho e autonomia no trabalho. Sociologia, Problemas e Práticas, 52, 41-65. Em https://bit.ly/31svS5t

Lee, E. (1980). Uma teoria sobre migração. Em H. A. Moura (coord.), Migraçâa interna: textos selecionados, 1 (pp. 89-114). Fortaleza: Banco do Nordeste do Brasil/Escritório Técnico de Estudos Econômicos do Nordeste (BNB/ETEne) (Versão original 1965).

Lei 9.478 de 6 de agosto de 1997. Dispóe sobre a política energética nacional, as atividades relativas ao monopólio do petróleo, institui o Conselho Nacional de Política Energética e a Agência Nacional do Petróleo e dá outras providências. Brasília, DF. Em http:// www.planalto.gov.br/ccivil_03/LEIS/L9478.htm

Monié, F. (2003). Petróleo, industrialização e organização do espaço regional. Em R. Piquet (org.), Petróleo, royalties e regiāo (pp. 257-285). Rio de Janeiro: Garamond.

Offe, C. (1989). Trabalho: A categoria-chave da sociologia? Revista Brasileira de Ciências Sociais, 4(10), 6-20. Em https://bit.ly/2XDK0X3 
Oliveira, A. T. R. (2006). Dos movimentos populacionais à pendularidade: uma revisão do fenômeno migratório no Brasil. Anais do XV Encontro Nacional de Estudos Populacionais. Caxambú, Minas Gerais: Associação Brasileira de Estudos Populacionais (ABEP). Em http://www.abep.org.br/publicacoes/index.php/anais/article/view/1606

Oliveira, S. R. \& Piccinini, V. C. (2011). Mercado de trabalho: múltiplos (des)entendimentos. Revista de Administração Pública, 45(5), 1517-1538. https://dx.doi.org/10.1590/ S0034-76122011000500012

Patarra, N. L. (2006). International migrations: theories, policies and social movements. Estudos Avançados, 20(57), 7-24. https://dx.doi.org/10.1590/S0103-40142006000200002

Piquet, R \& Terra, D. C. T. (2011). A roda da fortuna: a indústria do petróleo e seus efeitos multiplicadores no Brasil. Em R. Piquet (org.), Mar de riqueza, terras de contrastes. o petróleo no Brasil (pp. 11-48). Rio de Janeiro: Mauad X, Fundação de Amparo à Pesquisa do Estado do Rio de Janeiro (FAPERJ).

Rappel, E. (2003). Oportunidades e desafios do parque nacional de fornecedores de bens e serviços para o setor de petróleo e gás. In R. Piquet (org.), Petróleo, Royalties e Região (pp. 95-121). Rio de Janeiro: Garamond.

Ravenstein, E. G. (1980). As Leis da Migraçẫo. In H. A. Moura (coord.), Migração interna: textos selecionados, 1 (pp. 25-88). Fortaleza: Banco do Nordeste do Brasil/Escritório Técnico de Estudos Econômicos do Nordeste (BNB/ETENE) (Versão original 1885).

Silva, R. D. \& Matos, M. V. M. (2016). Petróleo e desenvolvimento regional: o Rio de Janeiro no pós-boom das commodities. Revista de Desenvolvimento Econômico (RDE), 2(34), 704-722. https://revistas.unifacs.br/index.php/rde/article/view/4437

Singer, P. (1980). Migraçôes internas: consideraçôes teóricas sobre o seu estudo. In H. A. Moura (coord.), Migração interna: textos selecionados, 1 (pp. 211-244). Fortaleza:Banco do Nordeste do Brasil/Escritório Técnico de Estudos Econômicos do Nordeste (BNB/ ETENE) (Versão original: 1976).

Sjaastad, L. A. (1980). Os custos e os retornos da migraçáo. In H. A. Moura (coord.), Migração interna: textos selecionados, 1 (pp. 115-144). Fortaleza: Banco do Nordeste do Brasil/ Escritório Técnico de Estudos Econômicos do Nordeste (вNB/ETENE) (Versão original: 1962).

Souza, J. \& Terra, D. C. T. (2015). Indústria petrolífera, mercado de trabalho e nível de dependência da mão de obra exógena nos municípios produtores de petróleo da Bacia de Campos, RJ. Revista Brasileira de Estudos Urbanos e Regionais (REBEUR), (17), 123143. Em http://rbeur.anpur.org.br/rbeur/article/view/4972/0

Souza, J. \& Terra, D. C. T. (2017). Rio de Janeiro: rumo a uma nova região metropolitana? Cadernos Metropole, 19(40), 817-840. https://doi.org/10.1590/2236-9996.20174006

Souza, J.; Terra, D. C. T. \& Campos, M. M. (2015). Mobilidade populacional e as novas espacialidades urbanas: Municípios da Ompetro, Rio de Janeiro (2000-2010). EURE (Revista Latinoamericana de Estudios Urbano Regionales), 41(123), 53-80. https://doi. org/10.4067/s0250-71612015000300003

Terra, D. C. T., Oliveira, E. L. \& Givisiez, G. H. (2012). A reestruturação econômica e territorial do Norte-fluminense. In F. Moniè \& J. Binsztok (orgs.), Geografia e Geopolítica do Petróleo. Rio de Janeiro: Mauad X. 
Terra, D. C. T. \& Souza, J. (2016). A importância da mobilidade populacional para a acumulação capitalista no setor Petróleo e gás da Bacia de Campos, RJ. Em G. J. Marafon \& M. Angelo (orgs.), Revisitando o Território Fluminense VI. Rio de Janeiro: Editora da Universidade do Estado do Rio de Janeiro (Eduerj).

Todaro, M. P. (1980). A migração da máo de obra e o desemprego urbano em países subdesenvolvidos. Em H. A. Moura (coord.), Migração interna: textos selecionados, 1 (pp. 145-172). Fortaleza: Banco do Nordeste do Brasil/Escritório Técnico de Estudos Econômicos do Nordeste (BNB/ETENE) (Versão original: 1969). 